\title{
SUSTAINABLE RURAL DEVELOPMENT THROUGH IMPROVING WATER SUPPLY IN MOUNTAIN HUTS
}

\author{
Diana Foris ${ }^{1}$, Dr.Eng./ Assist. Prof.; Danut Tokar ${ }^{2}$, PhD Student / MA, \\ Adriana Tokar ${ }^{3}$, Dr.Eng./ Assoc. Prof., Tiberiu Foris ${ }^{4}$, Dr. oec/ Prof. \\ ${ }^{1}$ Faculty of Food and Tourism, Transilvania University of Brasov \\ 2, 3 Faculty of Civil Engineering, University Politehnica Timisoara \\ ${ }^{4}$ Faculty of Economic Sciences and Business Administration, Transilvania University of Brasov
}

\begin{abstract}
Among the issues of the public services of economic interest, the water supply of urban and rural localities (areas where investment in this sector is limited) is of particular importance in maintaining social cohesion, raising the quality of life and ensuring sustainable development. The purpose of this analysis is to propose solutions for insuring and improving the water supply of isolated consumers in mountain rural areas, which is why a mountain tourist mountain hut has been chosen for this study. In this context, this paper addresses as a solution for the sustainable management of natural resources the use of rainwater. It is proposed to redesign the sanitary installation so that plumbing items that do not require drinking water can be fed through a separate installation. The proposed solutions are based on a comparative analysis of the microbiological parameters and the quality indicators between precipitation water and spring water with which the mountain hut is fed by an individual system. It is concluded that the recovery, storage and the use of the rainwater plays an important role in ensuring the supply of drinking water for the mountain cabin during periods when the water flow of the spring is low (in winter) and it contributes significantly to saving the freshwater resource in the area where the mountain hut is located.
\end{abstract}

Key words: rural development, water supply, rainwater harvesting, mountain huts.

JEL code: O18, R00, Q56, Q57

\section{Introduction}

The White Paper has introduced a new concept of democratic partnership between different levels of government in Europe and it deals with issues of public services of general economic interest and water supply and sewerage, considering them to be of particular importance for maintaining social cohesion, raising quality of life on the European continent and ensuring sustainable development (Romanian Water Association, 2009). Given that water is an important natural resource and the amount of rainfall decreases, a responsible use of rainwater in an ecological and natural way is a solution for sustainable management of the natural resources. The specialized literature provides extensive information regarding forecasts on the global water potential (Graham, 2006; Liu, 2009; Liu, 2010; Falkenmark, 2006; Foris, 2017; Rockstrom, 2015; Tokar, 2016; Vorosmarty, 2000). Although Romania's water resources potential is of 6450 $\mathrm{m}^{3} /$ year/person, a figure much higher than the European average of $4000 \mathrm{~m}^{3} / \mathrm{year} /$ person (Romanian Water Association, 2009),

In Romania, the drinking water supply for the inhabitants of rural settlements is not completely assured through centralized water supply systems. Generally, in areas with significant hydrographic potential and large accumulations of water, potable water supply and distribution networks have been built with own or European funds, but there are still settlements, especially in the hill and mountain areas, where villagers use water from their own individual systems (fountains, springs etc.). Generally, the investments were made where there were large human agglomerations, and the rural localities with few households have not come to the attention of the authorities. (Bocioaca C., 2017). It is important to bear in mind that the public water supply and the sewerage services play a vital role in improving the quality of life of all citizens and in combating social exclusion and isolation, and there is no need to distinguish between urban or rural localities, large ones or those with few households or between the ones in the lowlands or those in the highlands. 
Therefore, increasing the access of the population to these services, regardless of the type of locality, is absolutely necessary.

The article analyses the improvement of the water supply of isolated consumers in the mountain areas, which is why it refers to the tourist mountain huts. The tourist lodge is a relatively low capacity touristic structure, functioning in an independent building, with a specific architecture that ensures accommodation, food and other specific services necessary to the tourists who are hiking or resting in mountain areas, in natural reservations, near spa resorts or other touristic objectives (Order 65/2013, Annex 1.3). The classification of the mountain huts in Romania is mandatory and is made on stars, according to three categories of classification, 1, 2 and 3 stars respectively. The sanitary equipment is one of the sets of mandatory minimum criteria for the classification of the mountain huts. For this purpose, in the 3-star category, the rooms have to have a bathroom (bowl with shower, wash-basin and WC) of at least $25 \%$, common sanitary group in the cabin, separated by gender, consisting of: 1 shower cabin with hot water/cold for 15 persons; in the 2 and 1-star category, it must have common sanitary unit in the cabin, separated by gender, composed of: $1 \mathrm{WC}$ cabin for 10 persons (separated from the ones serving the public catering unit), 1 washer with washbasin with hot water, hot/cold for 10 persons. In the 1-star category, dry towel and outside washers are also available, powered by natural sources or reservoirs. Another mandatory minimum criterion involving water supply is its existence within the cabin of a public catering establishment involving a hot/cold water sanitary group, except for the 1-star cabins located in hard-to-reach areas where they also allow meals to be prepared and served.

In Romania, mountain huts were built almost in all mountain areas, but most of them have deteriorated over time or simply disappeared. The authors chose for this study a tourist mountain hut from The Postavaru Mountains, which is not supplied with water from public systems and operates both in winter and summer, and which is visited by a large number of tourists. The Postavaru Massif is part of The Curvature Carpathians, forming together with The Piatra Mare Massif The Barsa Mountains Group. It is located between the Intra-Carpathian Depression of Brasov, over which it rises at $1200 \mathrm{~m}$ and the steep northern slope of The Bucegi Mountains (The Postavaru, Great ..., 2018). In The Postavaru Massif, there are currently five tourist mountain huts.

The study was conducted for The Postavaru Hut - Julius Römer Hutte, situated in The Postavaru Mountains, in the Poiana Brasov area, the largest and the most popular ski resort in Romania. It is necessary to mention the fact that the water supply of the cabin is made by an individual system using a nearby spring as a source of water. One problem of providing the necessary amount of water in the mountain hut is the reduced water flow of the source used (spring) in the winter. For this reason, the paper analyses the solutions that can be adopted for the water supply of The Postavaru Hut - Julius Romer Hutte. As the basis of this study, the authors have used hydrological, climatic, meteorological information and analysis of the quality indicators for the potential water sources from which the mountain hut can be fed (The Postavaru, Great ..., 2018). Given the rather limited existence of the water sources in the area, meteoric waters can be an alternative to replacing a quantity of drinking water needed for the cabin's own consumption or supplementation if the incoming flow rate used does not cover the water demand for consumption. All of this information has been used to determine whether the recovery of the meteoric water can be a sustainable solution for the water supply of the cabin during periods when the flows of the natural sources in the area are insufficient. 


\section{Research results and discussion}

The Postavaru Hut - Julius Romer Hutte was founded in 1883 and is situated in The Postavaru Massif at an altitude of $1604 \mathrm{~m}$ (5262 ft) (Fig. 1).

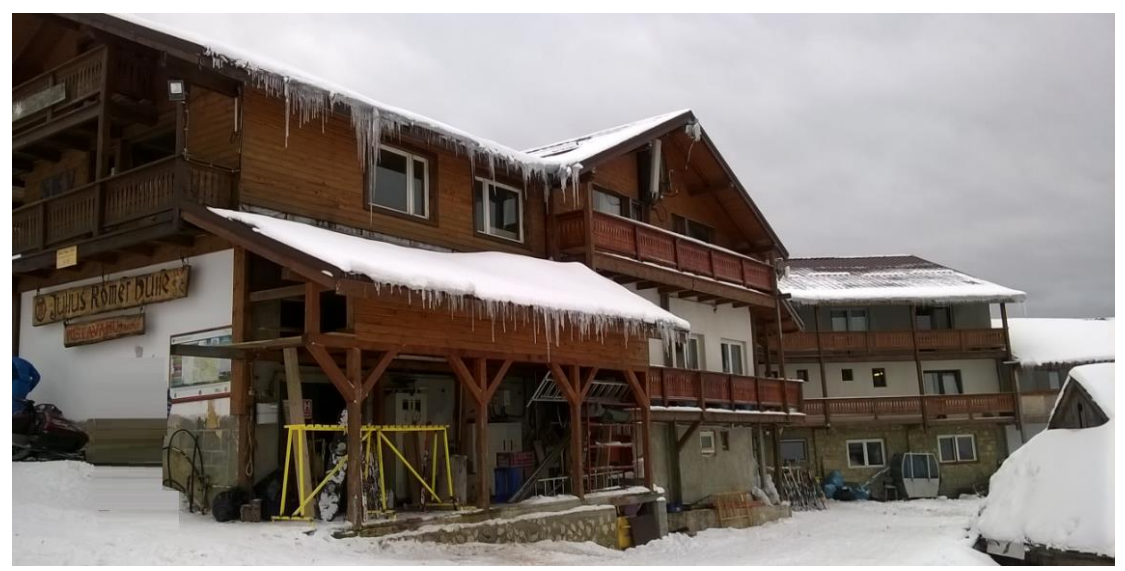

Fig. 1. The Postavaru Hut - Julius Romer Hutte

The Postavaru Mountains are part of The Curvature Carpathians and are developed on Cretaceous conglomerates. Hydrological information indicates that The Postavaru Mountains are drained by a hydrographic network with many waterfalls and a series of shorter tributaries. The higher courses are intermittent, they have a torrential character, presenting in longitudinal profile numerous cascades and slopes. In the parts where the waters pass through limestones or screes, they are lost underground only to appear downstream as powerful springs. The highest flows are recorded in spring, in April and early summer, due primarily to the melting of the snow and of long-lasting rain that find water-saturated soil. In the summer, during torrential rains, short but powerful floods can be formed, which can aggravate access on the valleys. At the end of the summer and autumn, the streams have the lowest debits due to reduced rainfall (Mountain Guide Postavarul ..., 2018). Based on these considerations, it can be concluded that the storage of meteoric waters collected during periods of abundance of precipitation is a solution for ensuring the water demand for isolated buildings, as is the case with The Postavaru Hut.

The annual rainfall amounts vary between $1100 \mathrm{~mm}$ in the Postavaru high section and $700 \mathrm{~mm}$ at the foot of the mountain. The highest rainfall falls in June (100-140 mm), and the lowest in September and February. In general, spring and early summer are the rainiest periods (Mountain Guide Postavarul ..., 2018). Although the first snowfall can be recorded in some years in September, the continuous snow blanket usually begins laying in October and may last until the end of April in Poiana Brasov. In the high part of Postavarul, snow can last about 200 days a year, which is about $55 \%$ of the calendar year (Mountain Guide Postavarul ..., 2018).

The mountain hut has a capacity of 100 seats with rooms for 2-6 persons equipped with bathrooms or shared bathrooms and a dining room with kitchen serving 100 people. Considering the technical condition of the meteorological water collection and discharge facility (Fig.2), investments are needed at least for the rehabilitation of this type of installation. In this context, the solution of redesigning of the indoor sanitary facilities was analysed so that the sanitary items that do not require drinking water (toilet tanks, both for the bathrooms of the accommodation rooms and for the sanitary groups adjoining the dining room, the maintenance of the hygienic sanitary facilities in the building, washing machines etc.) to be fed by a different installation from the drinking water supply (washbasins, washers, showers, bathtubs etc.). 

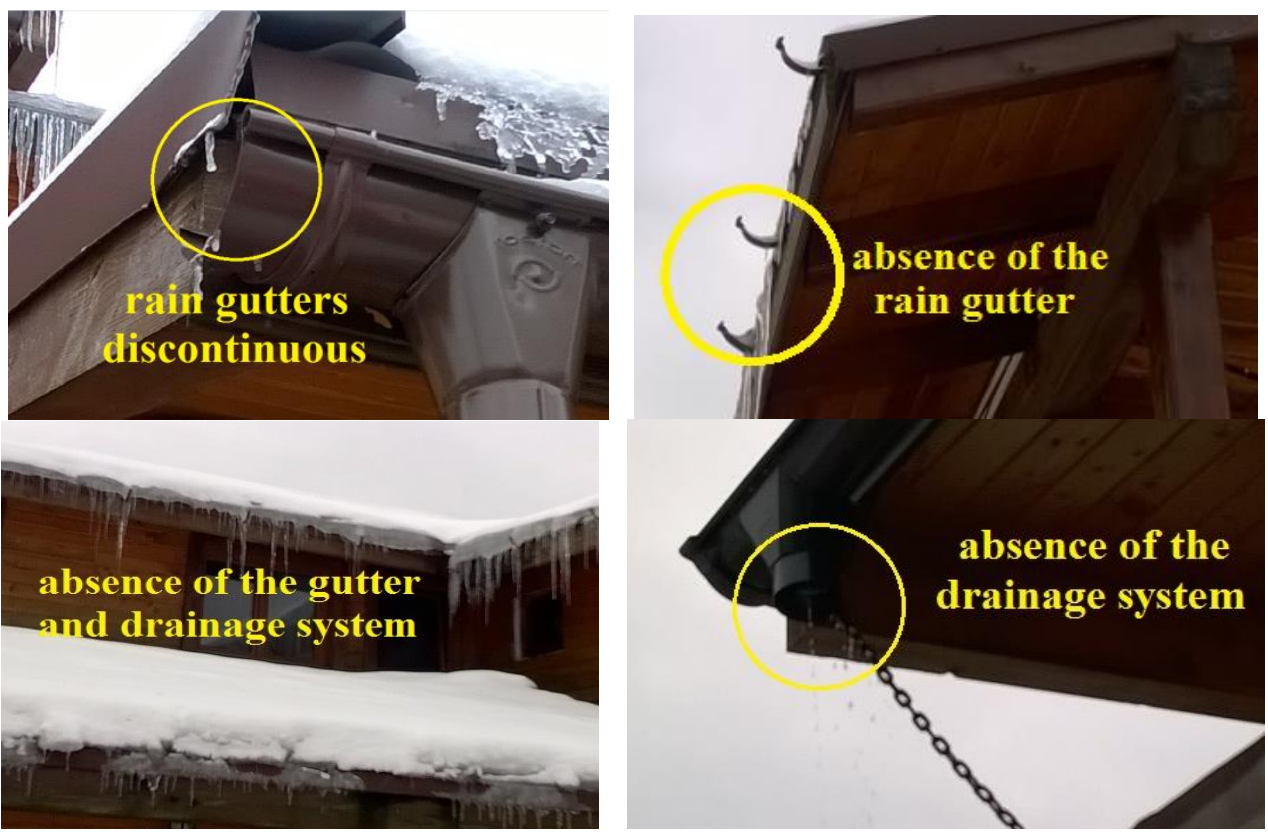

Fig. 2. Highlights of the technical state of the meteorological water collection and evacuation system

As mentioned above, the amount of precipitation varies greatly between the four seasons, but the annual rainfall being estimated at $1100 \mathrm{~mm}$, in the high section of Postavaru, where the mountain hut is located, it offers considerable potential for supplying the mountain hut. Studies conducted for the period 2090-2099 for the assessment of the rainwater regime in Romania indicate for the climate models that more than $90 \%$ of them will be affected by drought in the summer (with deviations higher than $20 \%$ compared to the reference years 1980-1990), and for the winter periods, the deviations are lower, but the uncertainty is higher (Guide on adapting ..., 2008). The collection and storage of the meteoric waters is the proposed option for the water supply of the sanitary items that do not require drinking water during the winter, when the water flow of the spring, which represents the water supply of the mountain hut, is low, failing to meet the water requirements.

In order to assess the possibility of using rainwater, an analysis of the physico-chemical and bacteriological parameters of the collected water from rainwater collecting and evacuation facilities was carried out. Considering the proposal for the use of collected meteorological waters, only for sanitary objects that do not require potable water consumption, the following water quality indicators were analysed: nitrates, nitrites, $\mathrm{PH}$, ammonium, chlorides, total number of germs (NTG) at $22^{\circ} \mathrm{C}$ and $37^{\circ} \mathrm{C}$, coliform bacteria, E-coli bacteria and Enterococi. The water samples were collected in plastic containers and analysed in the laboratories of The Public Health Directorate (DSP) Brasov (Water quality indicators ..., 2018), RENAR accredited laboratories.

Considering that the collected water is not used immediately, a storage being required, the water samples were analysed 12 hours after collection and then after 7 days of storage. The sample analysed after 7 days was stored in plastic containers in the dark at a temperature of $0^{\circ} \mathrm{C}$. The storage temperature was set at $0^{\circ} \mathrm{C}$ given that the underground storage capacity of the storage tanks (under $1.5 \mathrm{~m}$ in the area under consideration) is quite limited taking into account the large differences in the curvature level of the mountain hut site. Although there are solutions to avoid water frost, the underground storage of tanks under frost is also recommended for keeping water quality (microorganisms do not develop). In this study, the water quality was analysed 
globally, the results of the analyses being interpreted by reference to national water quality limits (Puchianu, 2015). It is necessary to emphasize that for the internal sanitary installations for water supply of WC tanks and washing machines, it is not necessary for the water to meet drinking conditions; however, the parameters analysed in this study are part of the parameters required for quality assessment of the drinking water. For a comparative assessment of rainwater quality, analyses were also carried out on a sample of water collected directly from the internal sanitary water system in its own water supply system that captures a spring.

Table 1 presents the results of the Quality Indicators in which the maximum admissible concentrations (MCAs) are specified in accordance with 458/2002 Law on drinking water quality, with subsequent modifications and completions or the limit of quantification (LOQ), as well as the method used.

Table 1

\section{Quality indicators and microbiological parameters of meteoric water and drinking water}

\begin{tabular}{|c|c|c|c|}
\hline Quality indicator & Measured value (UM) & Admissible values (UM) & Method \\
\hline \multicolumn{4}{|c|}{ Sample rainwater collected - stored for 12 hours } \\
\hline Total hardness & 2.34 German degree & Min.5 & SR ISO $6059 / 2008$ \\
\hline Nitrates & $2.8 \mathrm{mg} / \mathrm{l}$ & $50 \mathrm{mg} / \mathrm{l}$ & Fast test Spectoquant NOVA \\
\hline Nitrites & $0.24 \mathrm{mg} / \mathrm{l}$ & $0,5 \mathrm{mg} / \mathrm{l}$ & SR EN 26777:2002/C91:2006 \\
\hline PH & 5,9 & $6.5-9$ & SR ISO 10523:2012 \\
\hline Ammonium & $0.32 \mathrm{mg} / \mathrm{l}$ & $0.5 \mathrm{mg} / \mathrm{l}$ & Fast test Spectoquant NOVA \\
\hline Chlorine free-chlorine & $7.0 \mathrm{mg} / \mathrm{l}$ & $250 \mathrm{mg} / \mathrm{l}$ & SR ISO 9297:2001 \\
\hline NTG la $22^{\circ} \mathrm{C}$ & $19 \mathrm{ufc} / 100 \mathrm{ml}$ & $100 / \mathrm{ml}$ & SR EN ISO 6222:2004 \\
\hline NTG la $37^{\circ} \mathrm{C}$ & $17 \mathrm{ufc} / 100 \mathrm{ml}$ & $20 / \mathrm{ml}$ & SR EN ISO 6222:2004 \\
\hline \multicolumn{4}{|c|}{ Sample rainwater collected - stored for 7 days } \\
\hline Total hardness & 2.75 German degree & Min. 5 & SR ISO $6059 / 2008$ \\
\hline Nitrates & $1.8 \mathrm{mg} / \mathrm{l}$ & $50 \mathrm{mg} / \mathrm{l}$ & Fast test Spectoquant NOVA \\
\hline Nitrites & $0.35 \mathrm{mg} / \mathrm{l}$ & $0,5 \mathrm{mg} / \mathrm{l}$ & SR EN 26777:2002/C91:2006 \\
\hline PH & 6.4 & $6.5-9$ & SR ISO 10523:2012 \\
\hline Ammonium & $0.32 \mathrm{mg} / \mathrm{l}$ & $0.5 \mathrm{mg} / \mathrm{l}$ & Fast test Spectoquant NOVA \\
\hline Chlorine free-chlorine & $12.6 \mathrm{mg} / \mathrm{l}$ & $250 \mathrm{mg} / \mathrm{l}$ & SR ISO 9297:2001 \\
\hline NTG la $22^{\circ} \mathrm{C}$ & $21 \mathrm{ufc} / 100 \mathrm{ml}$ & $100 / \mathrm{ml}$ & SR EN ISO 6222:2004- \\
\hline NTG la $37^{\circ} \mathrm{C}$ & $18 \mathrm{ufc} / 100 \mathrm{ml}$ & $20 / \mathrm{ml}$ & SR EN ISO 6222:2004 \\
\hline \multicolumn{4}{|c|}{ Drinking water sample collected from the water supply plumbing of the mountain hut } \\
\hline Total hardness & 2.55 German degree & Min.5 & SR ISO $6059 / 2008$ \\
\hline Nitrates & $3.4 \mathrm{mg} / \mathrm{l}$ & $50 \mathrm{mg} / \mathrm{l}$ & Fast test Spectoquant NOVA \\
\hline Nitrites & $0.37 \mathrm{mg} / \mathrm{l}$ & $0.5 \mathrm{mg} / \mathrm{l}$ & SR EN 26777:2002/C91:2006 \\
\hline PH & 6.4 & $6,5-9$ & SR ISO 10523:2012 \\
\hline Ammonium & $0.37 \mathrm{mg} / \mathrm{l}$ & $0.5 \mathrm{mg} / \mathrm{l}$ & Fast test Spectoquant NOVA \\
\hline Chlorine free-chlorine & $7.8 \mathrm{mg} / \mathrm{l}$ & $250 \mathrm{mg} / \mathrm{l}$ & SR ISO 9297:2001 \\
\hline NTG la $22^{\circ} \mathrm{C}$ & $24 \mathrm{ufc} / 100 \mathrm{ml}$ & $100 / \mathrm{ml}$ & SR EN ISO 6222:2004- \\
\hline NTG la $37^{\circ} \mathrm{C}$ & $18 \mathrm{ufc} / 100 \mathrm{ml}$ & $20 / \mathrm{ml}$ & SR EN ISO 6222:2004 \\
\hline
\end{tabular}

In addition, along with the water quality indicators and water microbiological parameters presented in Table 1 for the water samples, the presence of coliform bacteria, E-coli bacteria and enterococci were also analysed. The analysis did not indicate the presence of these microbiological parameters in any of the analysed samples. 
Considering that the proposed solution for the use of meteoric waters does not imply the supply of sanitary objects requiring drinking water, the low value of the total hardness for all analysed samples cannot be interpreted as a disadvantage. It is well known that low water hardness values are favourable to the proper operation of water supply facilities by reducing the risk of deposits on the installations' piping. There is, however, an increase in total water hardness after 7 days of storage.

The recorded values for nitrates, nitrites, ammonium and chlorides fall below the detection limits, with close values between meteoric water and spring water. Although there is an increase in chlorine value after 7 days of storage for the rainwater sample, this is well below the permissible limit and there are no grounds for concern for the corrosion of the meteorological water pipe installations.

The PH analysis indicates a slightly acidic character, which does not adversely affect the decision to collect, store and use meteoric waters. After analysing the test results for the number of colonies at $22^{\circ} \mathrm{C}$ and $37^{\circ} \mathrm{C}$, it appears that this parameter does not show any abnormal change for the analysed samples. For meteorological water samples, a slight increase in colonies counts is observed at $37^{\circ} \mathrm{C}$ between the 12 -hour analysis and the 7-day storage. The presence of mesophilic flora in the water allows the assessment of the sanitary conditions and of the drinking water quality, but the values do not exceed the admitted value; therefore; there are no reasons to apply water chlorination methods.

In conclusion, with the exception of the total hardness, the water quality for the three samples subjected to the laboratory analyses, falls within the limits of the drinking capacity stipulated by the law and there are no notable differences between the values of the quality indicators and the microbiological parameters between the two sources of water (meteoric water and spring water). As far as the total hardness of the water is concerned, the classification below the limit stipulated by the law does not mean that it does not meet drinking conditions, but it indicates that it is low mineralized.

\section{Alternative solutions for water supply of the mountain huts}

The results of the microbiological parameters and quality indicators for the collected water samples are the main factor that has been taken into consideration when proposing solutions that provide an efficient water supply system for the mountain cabin. Other relevant factors that have been considered relate to the amount of the rainfall associated with the area and the potential of freshwater sources in the area.

The constructive solutions of the rainwater facilities, collected through gutter and drainage systems and stored in the underground or above ground tanks, can be made either by direct feeding of sanitary items from the underground/above ground storage tank or from an extra high tank located in the cabin floor where the water gets pumped from the underground/overground storage tank. In the case of a solution with an extra high tank, it will operate automatically when the water level in the underground/ overground storage tank is low. The control system is programmed to fill the network storage tank when there is not enough rainwater collected. For these installations, which supply the sanitary items in buildings, it is advisable to capture rainwater from the roofs of buildings through gutter and pipe systems. In order to maintain the quality of the collected water on the roof, it is necessary to inspect and clean the collection system periodically. 
The water frost problem in the collection system pipelines during the cold periods of the year can be avoided by installing the heater cable defrosting systems. These systems are mounted on the rooftops and on gutters with automation systems that start the heater system when sensing ice formations that can clog the rainwater collecting systems. Experimental studies on defrosting systems indicate their effectiveness (Langlois, 1999; Rusen, 2017).

Collecting rainwater from the ground is more problematic because it can be contaminated and will require additional cleaning. However, contamination cannot be a problem if rainwater is only used to water plants or clean outdoor terraces, and if it is also used to supply sanitary items in the buildings, it needs treatment according to contaminants. In the case of roof-collecting, simple, nondisinfecting filtration is sufficient to allow rain water to be used to wash the floors of the cabin, to fill the toilet tanks and to feed the washing machines. The filters can be positioned on the rainwater collection system or in the underground tank, depending on the most economical option. The efficiency of a filter mounted on the rainwater collection system is high when the meteor shower is clean, but it will drop significantly if it is not cleaned regularly. The storage tanks will be placed underground as priority because light and high temperature favour the bacterial growth. However, annually, tanks should be inspected to check for sludge accumulation and need to be washed with calcium hypochlorite. To raise water pressure in the sanitary installations of using reused water, pumps are required. From the point of view of the safety of the supply of the sanitary plumbing requiring drinking water, the rainwater utilization facilities will be appropriately marked and no connections will be made between these installations and the sanitary facilities that supply sanitary plumbing that requires drinking water. The description of the solutions is basic so they can be complemented with safety and automation elements, depending on the local situation, the area where it is installed and the type of sanitary items.

\section{Conclusions, proposals, recommendations}

1) A sustainable development implies the preservation of ecosystems, and their protection is conditional on sustainable development. Through its essential coordinates, the strategy of environmental protection is therefore found in the strategy for sustainable development of urban and rural localities.

2) The water protection measures - as a vital resource - are defined in close connection with the economic development policy and with the medium and long-term economic and social forecasts. The society and the economy must work, and the protection of freshwater and, implicitly, the environment must be done at all costs.

3) The study was conducted to exemplify the improvement of the water supply of an isolated consumer from a mountain area, which is why it refers to tourist mountain huts. In order to establish an efficient solution in terms of reduction of fresh water consumption, as well as to ensure the necessary of the water supply in the mountain hut, the opportunity to use rain water was used as a source of water supply. In this respect, the analysis of the pluviometric potential in the area, where the mountain hut is located, as well as the microbiological parameters and the rainwater quality indicators, show the meteoric water as a potential source of water supply.

4) The study shows that the meteoric water meets the drinking conditions, but for the safety of the consumers, it is proposed to redesign the indoor sanitary facilities so that the sanitary items that do not require potable water supply are fed through a separate plumbing, as long as there 
is a sufficient quantity of collected and stored rainwater, as well as the possibility of supplying water from the drinking water supply system.

5) In strategies for the development and modernization of the public water service infrastructure, especially in the mountain rural localities, where there are often isolated consumers such as the mountain huts, it is necessary for the local authorities to develop their own strategies to ensure these consumers with appropriate and affordable quality services by promoting technical solutions correlated with the latest technologies.

6 ) In conclusion, the authors consider that the recovery, storage and the use of rainwater can play an important role in increasing the water security and it contributes significantly to saving freshwater resources in water-shortage and dry areas.

\section{Bibliography}

1. Bocioaca, C. (2017). Water - A Priority for the Villages, but not for the Mountains. World Village Magazine. No. 3, pp. 52-53.

2. Falkenmark, M., Rockstrom, J. (2006). The New Blue and Green Water Paradigm: Breaking New Ground for Water Resources Planning and Management. Journal of Water Resources Planning and Management. Vol. 132. No. 3, pp. 129-132.

3. Foris, D., Plesca, M. (2017). Sustainable Tourism through the Protection of Sweet Water Resources in Mountain Area. Bulletin of the Transilvania University of Brasov. Series II: Forestry Wood Industry Agricultural Food Engineering • Vol. 10 (59) No.1, pp. 107-112.

4. Graham, J. (2006). Integrating Blue and Green Water Flows for Water Resources Management and Planning. Physics and Chemistry of the Earth, Parts A/B/C. Vol. 31, No. 15-16, pp. 753-762.

5. Guide on Preparation of Master Plans for Water and Wastewater Projects. (2007). Bucharest: MESD, p. 34.

6. Guide on adapting to the effects of climate change. Ministry of Environment and Sustainable Development MMDD (2008). Retrieved: http://www.monitoruljuridic.ro, Access: 26.01. 2018.

7. The Strategy for Sustainable Development of Public Water Supply and Sewerage Services "Romania 2025". (2009). Bucharest: Romanian Water Association - ARA, p. 47.

8. Langlois, D. (2018). Fire Investigation Involving Electrical Heating Cable. Retrieved: https://iaeimagazine.org. Access: 28. 01. 2018.

9. Liu, J., Yang, H. (2010). Spatially Explicit Assessment of Global Consumptive Water Uses in Cropland: Green and Blue Water. Journal of Hydrology, Vol. 384. No.3, pp. 187-197.

10. Liu, J., Zehnder A. J, Yang, H. (2009). Global Consumptive Water Use for Crop Production: The Importance of Green Water and Virtual Water. Water Resources Research. Vol. 45, No. 5, pp. 1-15.

11. Mountain Guide Postavaru Mountains. Retrieved: http://www.carpati.org/ghid_montan/muntii/56/hidrografie//. Access: 30.01.2018.

12. Order no. 65/2013 For the approval of the methodological norms regarding the issuance of certificates for the classification of the tourist accommodation structures with functions of accommodation and public catering, licenses and tourism certificates.

13. Puchianu, G., Necula, V., Enache D.V., Necula V. (2015). Research on Microbiological Quality of Drinking Water Used in Some Establishments Slaughtering and Processing of Food of Animal Origin from Brasov County. The 3rd North and East European NEEFOOD Congress on Food. Global and Local Challenges in Food Science and Technology. Brasov, Romania.

14. Rockstrom, J., Lannerstad, M., Falkenmark M. (2006). Assessing the Water Challenge of a New Green Revolution in Developing Countries. Proceedings of the National Academy of Sciences of the United States of America. Vol. 104. No. 15, pp. 6253-6260.

15. Rusen, A. M., Scurtu, A., Craciun, A. (2017). Alternative Methods for De-Icing Dangerous Parts of the Road. Energy - Resources - Environment of the Students from Oradea. Oradea, Romania.

16.Stănescu, R., Sene, M., Volintiru, C. (2012). European Policies Guide, Brochure No. 4 - Environmental Policy. European Institute of Romania. 29 p.

17. The Postavaru, Great Stone and Baiului Mountains. Retrieved: http://muntii-nostri.ro/munte/muntiipostavaru-piatra-mare-si-baiului/. Access: 29.01.2018.

18. Tokar, A. (2016). Sanitary and Gas Installations. Part I. Timisoara: Politehnica, p. 333.

19. Tokar, A., Negoitescu, A. (2015). Treatment Solutions for Rainwater Contaminated with Various Pollutants. Annals of the University "Eftimie Murgu" Resita. Vol. XXII. No. 1, pp. 405-414.

20. Vorosmarty, C. J. Green, P., Salisbury, J., Lammers, R. (2000). Global Water Resources: Vulnerability from Climate Change and Population Growth. Science. Vol. 289. No. 5477, pp. 284-288.

21. Water Quality Indicators - Analysis Report. Public Health Directorate Brasov - PhD Brașov. (2018). p. 1. 